\title{
Tectonics and human evolution
}

\author{
Geoffrey King ${ }^{1} \&$ Geoff Bailey ${ }^{2}$
}

The authors propose a new model for the origins of humans and their ecological adaptation. The evolutionary stimulus lies not in the savannah but in broken, hilly rough country where the early hominins could hunt and hide. Such 'roughness', generated by tectonic and volcanic movement characterises not only the African rift valley but probably the whole route of early hominin dispersal.

Keywords: Africa, Rift Valley, human origins, hominins, H. erectus, H. ergaster

\section{Introduction}

The dominant conception of human origins during the past five decades has been one of a transition from vegetarian apes living mainly in trees to ground-dwelling humans exploiting the large game herds of the African savannah in response to increased global aridity and reduction of tree cover. The modern consensus is that this process first occurred in Africa, beginning at least as early as 4.5 million years ago with Ardipithecus ramidus, or perhaps earlier in the light of the recent finds in the Chad basin (Brunet et al. 2002) and Kenya (Senut et al. 2001), evolving through the Australopithecines, and leading to the evolution of the genus Homo after $2.5 \mathrm{Ma}$. The emergence of Homo erectus (or H. ergaster as some prefer) at $\sim 1.8$ million years ago, saw a capacity to range widely over open terrain, the widespread use of stone tools, a greater dependency on animal protein whether by scavenging or hunting, and dispersal more widely within and beyond Africa (Cachel \& Harris 1998; Delson et al. 2000; Klein 1999).

There are, however, some longstanding difficulties with the ecology of this process. As Carl Sauer presciently observed over 40 years ago:

'The various kinds of primates can be described as to their proper habitats: for early man [sic] there is no such agreement and the most familiar assignment of him to living in savanna plains is perhaps the least likely. He was not specialised for predation; he was inept at flight or concealment; he was neither very strong nor fast'. (Sauer 1962: 42)

The modern control of large plains is in fact a very recent development in human prehistory, dependent on the domestication of riding animals. The alliance between the horse and modern humans took place on the plains of Asia as late as 6000 years ago, and rapidly spread throughout Eurasia in subsequent millennia, followed in historical times by the conquest of the plains of the Americas and Australia (Clutton-Brock 1999; Keegan 1993).

1 Laboratoire Tectonique, Institut de Physique du Globe Paris, 4 place Jussieu, 75252 Paris, France (Email: king@ipgp.jussieu.fr)

2 Department of Archaeology, University of York, King's Manor, York, YO1 7EP, UK (Email: gb502@york.ac.uk) 
In more arid regions the camel played a comparable role over a similar time range. Even the hunting of large herbivore herds on the steppe-tundra of Pleistocene Europe and the grasslands of the Great Plains in North America seems to have appeared relatively late in the prehistoric sequence and perhaps in some regions only as a marginal and specialised adaptation (Dixon 2001). In historical times and in many places, indigenous populations were driven to the hills where the man-horse combination of their enemies could not penetrate. In modern conflict, motorised war machines have replaced the horse so that only in mountainous retreats, rough terrain or urban streets, can individuals or small bands hope for tactical advantage. An animal with our body form is disadvantaged in many ways in flat terrain but well adapted to morphologically complex environments, including evermore elaborate artificial structures. Leaving the trees to live on the savannah plains seems a paradoxical if not improbable strategy for the survival of early human populations, exposing them to greater risks and fiercer competition with better-adapted animals.

For Sauer, the resolution of this paradox lay in shorelines and coasts as environments most likely to select for early human characteristics such as bipedalism and tool-making, a proposal difficult to reconcile with the pattern of the currently available evidence (but see Erlandson 2001). For others, the persistence of trees, even as patchy resources, is cited as a potential refuge from danger. The development of bipedalism early on in the process of human evolutionary divergence, faunal and palaeovegetational associations suggesting well-wooded conditions in the period from about 4 to 2.5 million years ago and anatomical features in Australopithecines indicating continued adaptation to tree living lend some support to such a notion (Reed 1997; Rogers et al. 1994).

Here, we develop an alternative hypothesis, which focuses on complex topography and the role of active tectonics. The African Rift is a long-lived and active tectonic structure and one of the largest in the world, creating distinctive and topographically complex landscapes of fault-bounded basins, uplifted terrain, and ubiquitous volcanoes and lava fields that provided the local conditions for human survival. That it is also home to some of the most numerous and extensive finds of fossil and archaeological material relating to the earliest phases of human evolution is, we suggest, no coincidence, and indicates a relationship that deserves closer investigation (Figure 1).

Many authors have noted general linkages between human evolution and tectonic activity in relation to very large-scale trends such as climate change, speciation resulting from formation of geographical barriers at a continental scale, or increased opportunities for the exposure and discovery of archaeological and fossil finds (Coppens 1994; Gamble 1993, 1998; Partridge et al. 1995a, b; Partridge 1997; Redfield et al. 2004; Ruddiman \& Raymo 1988; Thomas 1985; WoldeGabriel et al. 2004). Others have drawn attention to the mosaic character of African Rift environments, creating variety of potential food resources, abundant surface water and opportunities for niche diversification and specialisation (Cachel \& Harris 1998; Foley 1995; Stern 1993). Here, we emphasise the creative role of underlying geodynamic processes in maintaining these mosaic environments and the distinctive topographic features associated with them. We argue that a key environmental factor in driving forward the process of human evolution is localised areas of topographic complexity resulting from active tectonics, where a ground dwelling bipedal omnivore could gain tactical advantage over faster moving quadrupeds, find protection from carnivore 


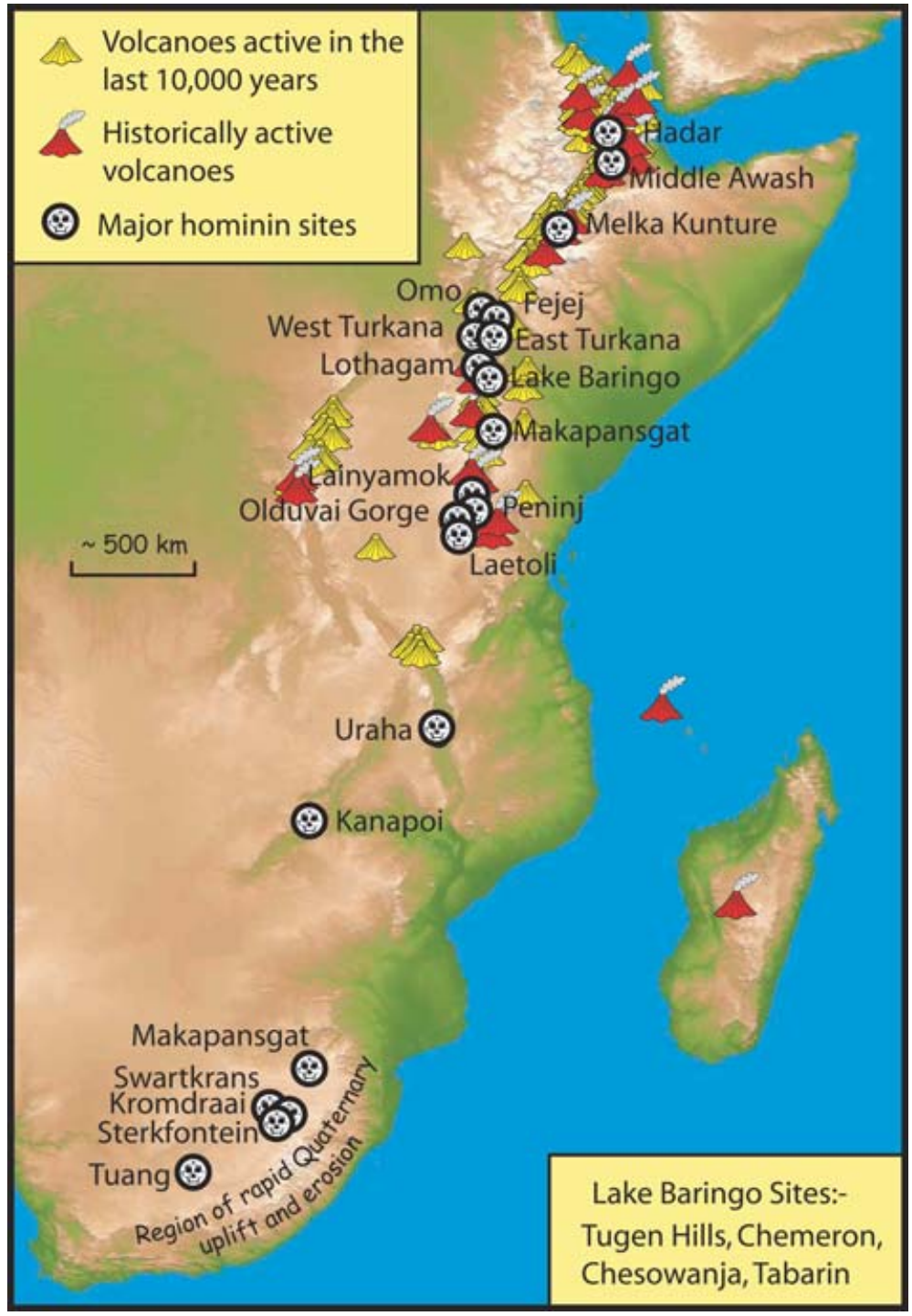

Figure 1. General indication of hominin sites in the African Rift and areas of volcanic activity.

predators and outmanoeuvre herbivore prey, thereby gaining access to the vast meat reservoir of the savannah plains, while also benefiting from other resources. Extensive areas of smooth and open terrain with their large biomass of mammal protein remain important in this hypothesis, but inaccessible except in combination with other physical features.

\section{Environmental requirements}

The biological and physiological changes associated with the development of a human niche, and the sorts of environmental conditions that would have selected for those changes, have been extensively discussed (for a broad review see Foley 1995, and elaboration by Aiello \& 
Wheeler 1995; Bunn 1994; Cachel \& Harris 1998; Potts 1988, 1996; Wheeler 1991). The key trends, about which there is general agreement, are increased ground dwelling and bipedalism, diversification of diet to include a wider range of foods including more emphasis on meat, increased body size and disproportionate increase in brain size, manufacture of stone tools, adaptation to heat stress, foraging over longer distances and a longer period of childhood immaturity and learning. These in their turn would have required regular water intake, increased consumption of animal protein, access to suitable stone for artefacts, and increased parental care and cooperation. This combination of developments would have opened up a meat-eating niche by facilitating access to animals and animal products inaccessible to other carnivores and scavengers, or at places and times when competition was less severe, during the day and in dry seasons, for example. Such behaviour would have entailed greater hazards and exposure to predation and required the creation of ground 'nests' using features such as cliffs and caves, social defence or fire, as trees became less accessible.

Feedback between different elements of this package is commonly emphasised, for example between daytime hunting, upright stance and physiological adaptation to heat stress, between stone tools, meat-eating and increased brain size, between increased brain size and cognitive skills in communication and problem-solving, and between cognitive skills, spatial memory and the use of larger and more environmentally diverse home-ranges. Other tendencies may have created new pressures. For example, the prolongation of childhood vulnerability and dependency on parental care would have imposed new pressures on the ability of females to feed themselves and their offspring independently of the males and the vicissitudes of their success in obtaining meat, and on the provision of ground nests safe from predator attack.

Of course, there is not universal agreement on when or how all these changes occurred. But there is a general recognition that many of these features had become integrated in a single, stable configuration by the time of emergence of Homo erectus, with further amplification in the course of subsequent evolutionary development of the Homo lineage.

Turning to the sorts of physical conditions that might favour these developments, the following stand out as key factors:

- a varied environment with a wide range and abundance of plants and animals offering new opportunities for obtaining food

- abundant and easily accessible water supplies

- secure locations where vulnerable individuals could find protection from attack by predators or other hazards, and food supplies within easy reach

- opportunities for the trapping of mobile or elusive animals

We suggest that the distinctive tectonics of the African Rift provide a unique geological environment that meets all of these environmental requirements and may indeed have contributed powerful selective pressures favouring the human trajectory.

\section{The extensional and volcanic environments of the African Rift}

Complex topography largely results from the interplay of two agents, uplift and deformation of the earth's crust by tectonic and volcanic activity, and the smoothing of relief by erosion. 
Active tectonics and volcanism create features such as faults and lava flows, which with repeated motion build mountains and valleys. Although erosion smoothes and in due time destroys the creations of tectonics, steep canyons, river terraces and lakes with changing shorelines can result in transitory but dramatic local relief.

The African continent shows unusually high levels of volcanic activity and this has been the case for 15 million years or more. This is now thought to result from the African plate becoming stationary above the underlying mantle $~ 30$ million years ago (Burke 1996; Scotese \& McKerrow 1991). The insulating blanket of continental lithosphere caused a rise in both crust and mantle temperature. As a result both the mantle and crust expanded (Anderson 1982), lifting the whole of Africa by about $1 \mathrm{~km}$. The great African escarpment that runs all along the southern coast of Africa to the Zambezi valley on the east coast and to Luanda on the west is the most spectacular manifestation of this uplift. Deep down-cutting of the major rivers such as the Zambezi, Limpopo and Nile, and rapid progradation of their deltas, can be dated to this period (Burke 1996; Moctar Doucouré \& de Wit Maarten 2003).

Heating in the mantle also resulted in melting, expressed as extensive volcanism at the surface. In one school of thought, the process of magma forcing upwards from the mantle has caused the African plate to split apart along the East African Rift. The alternative view that Africa is being pulled apart by plate motion, ascendant when plate tectonic concepts were new, is now losing adherents (Davidson et al. 2002). Irrespective of the long-term processes, the African Rift is associated with extension, and the normal faulting that accompanies it, in which uplift of the rift flanks is associated with subsidence of the floor (cf. Armijo et al. 1996; King \& Ellis 1990) and exceptionally high levels of volcanic activity. It is in such environments that earliest humans first secured a niche.

Repeated earthquakes and volcanic activity are associated with subsidence of the rift floor and uplift of the adjacent flanks to create internally draining basins that trap water and sediments to create fertile lake environments and alluvial plains. The resulting landscape is punctuated by numerous volcanic lava flows, traversed by rivers and circumscribed by fault scarps that can form nearly vertical cliffs adjacent to local basins of subsidence that fill with water and sediment. The result is a complex topography of sedimentary basins and physical barriers at a variety of geographical scales, ranging from the extremely localised, over distances of hundreds of metres to kilometres, to larger regional scales. These provide a diversity of resources - local concentrations of plant foods and animals attracted to the shores of lakes and rivers, drinking water and aquatic foods at the shore edge - and nearby locations enclosed by lava flows or backed by fault scarps and incised river terraces (Figures 2 and 3).

Volcanoes in the African Rift erupt a range of lavas, although basalt lavas are the most common and account for the greatest volume by a large margin. Although basalt is usually very fluid and can flow for long distances, the cooled surface breaks into blocks, creating a surface of often razor sharp angular blocks known as 'Aa', named in Hawaii, where examples are common and the ages are known in detail (Figure $3 \mathrm{f}$ ). The one illustrated is $c$. 10000 years old, indicating that such flows can last as obstacles for long periods of time, even in regions of substantial rainfall and consequent erosion. Enclosed areas resulting from lava flows and faults are called Kapuka in Hawaii. Today, some native plant species only survive 


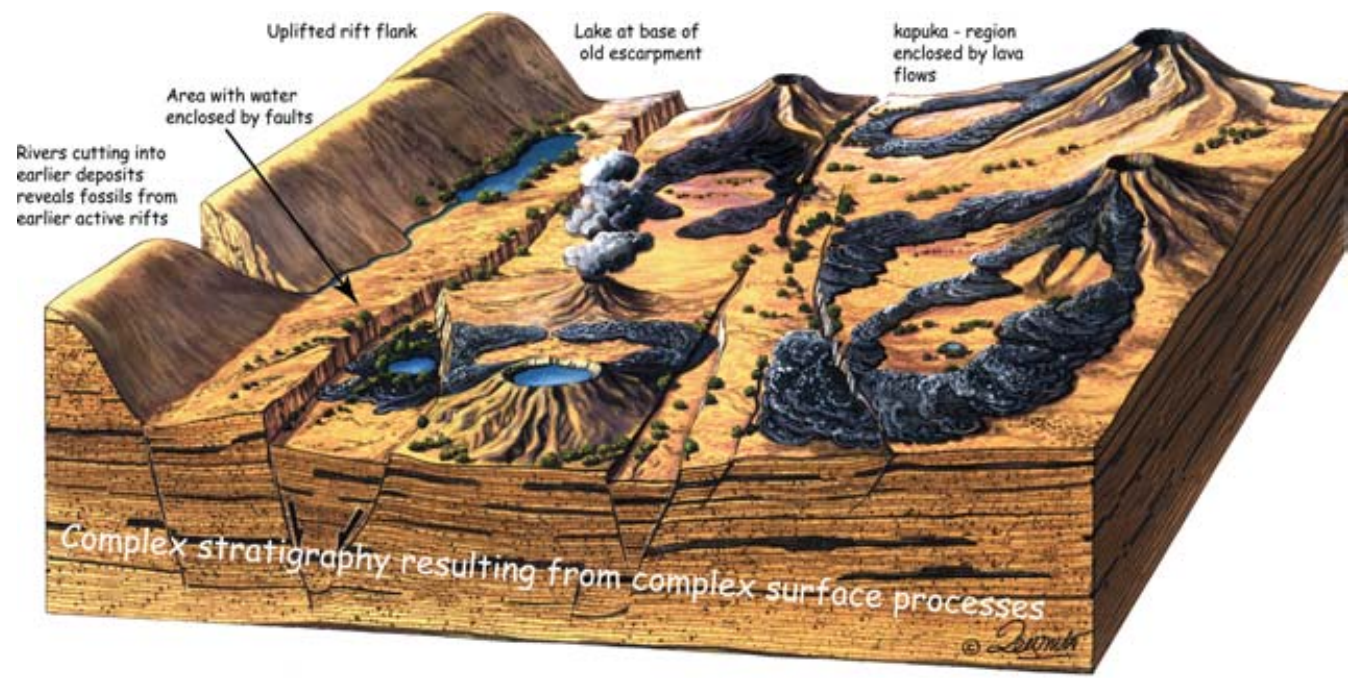

Figure 2. A cartoon representation of features associated with an active rift. An older smoothed escarpment is shown to the left. A river is shown cutting a narrow gorge into the escarpment. Down-cutting of uplifted rift flanks is responsible for revealing fossils in earlier rift floor sediments. The view shows a lake at the base of the older escarpment. Springs, small lakes or wet areas commonly appear on the down-dropped sides of faults, which form near vertical escarpments within the active rift. Lava flows form barriers and often create enclosed regions (Kapuka). Distances between the faults, volcanoes and lava flows have been contracted for the purposes of the cartoon. The flat areas between the features are typically more extensive than indicated and exhibit savannah characteristics.

in Kapuka, where they find protection from introduced wild pigs. In the past, Kapuka were also of tactical importance in warfare and feature in Hawaiian mythology.

Similar lava flows are common features of the African Rift landscape. They are, of course, important as sources of stone for artefacts, but they also offer other advantages. They can create localised sediment and water traps enclosing small and well-protected pockets of fertility. They also form formidable obstacles to rapid movement, either as near vertical but low barriers $2-3 \mathrm{~m}$ high consisting of angular rocks, or as more extensive lava fields. When young, these lava fields are anything but smooth, representing a jumble of jagged rocks. Even when exposed to tens of millennia of erosion and rounding of the sharper edges, they remain as densely packed boulder fields that can only be traversed slowly or with difficulty.

There is no other part of the world with such a large or long-lived tectonic feature dominated by volcanism and extensional tectonics. Similar extensional environments occur in Iceland and New Zealand but extension in such places as Europe, Arabia and China is not associated with similar levels of volcanic activity. A key point about the African Rift is that tectonic activity has been continuous throughout the time span of human existence. The level of activity has varied locally and the focus has shifted but the overall level has remained high. This means that all the features described above are being continuously rejuvenated, though not necessarily in the same places in the landscape or in exactly the same configuration. Landscapes that were subjected to high levels of tectonic activity at some remote period and became quiescent would lose sharpness and detail and tend towards greater environmental uniformity. The long-term persistence of environmental variability and of sharp topographic barriers such as lava flows and fault scarps is thus a distinctive feature. 

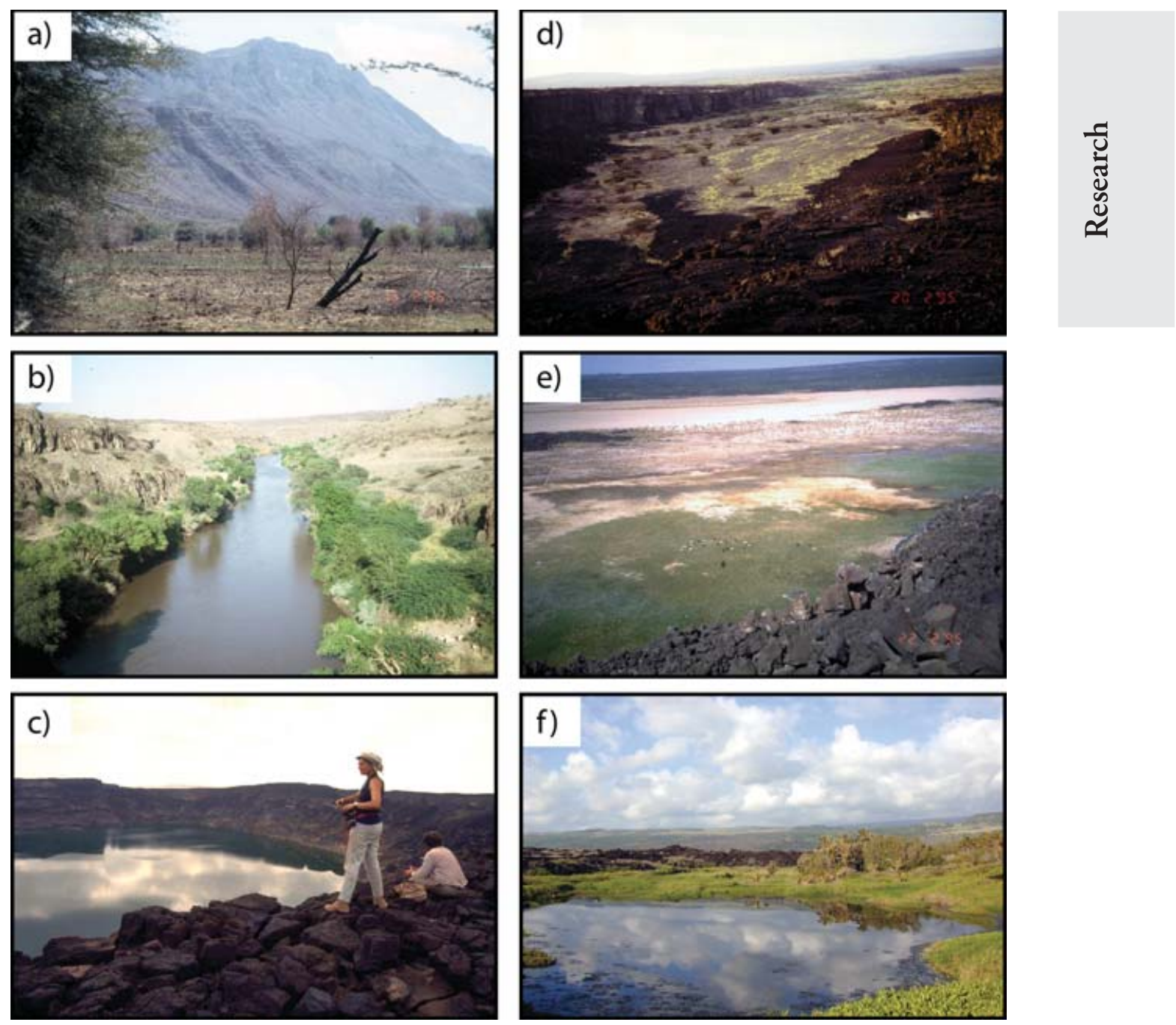

Figure 3. Features associated with active rifting. Figures 3(a) to (e) are from the Afar region of Ethiopia, Figure 3(f) from Hawaii. (a) Escarpment near the eastern end of Lake Gamori, Ethiopia. (b) The Awash River cutting into the uplifted rift flank bounding the currently active rift. (c) The caldera of a volcano lying on the axis of the active rift, filled with freshwater. (d) Active faults resulting from active rifting cutting the flank of the volcano in Figure 2(c). (e) Subsidence associated with an active fault on the rift axis creating a 'well watered' region. $(f)$ A lava flow in the humid region of Hawaii. The 10ka flow is only modestly eroded.

It is not difficult to see how an unspecialised ground-dwelling predator, dependent on powers of observation and intelligence rather than of speed and strength, might use local barriers and enclosures created by a topography of lava flows and fault scarps as a secure place for ground nesting, for feeding at leisure on food brought in from elsewhere, as a source of local food and water, and in time as a means of actively manoeuvring and diverting live animals from the edge of more open terrain into natural enclosures and traps. With an increased capacity to make use of topography in this way, early humans would become 


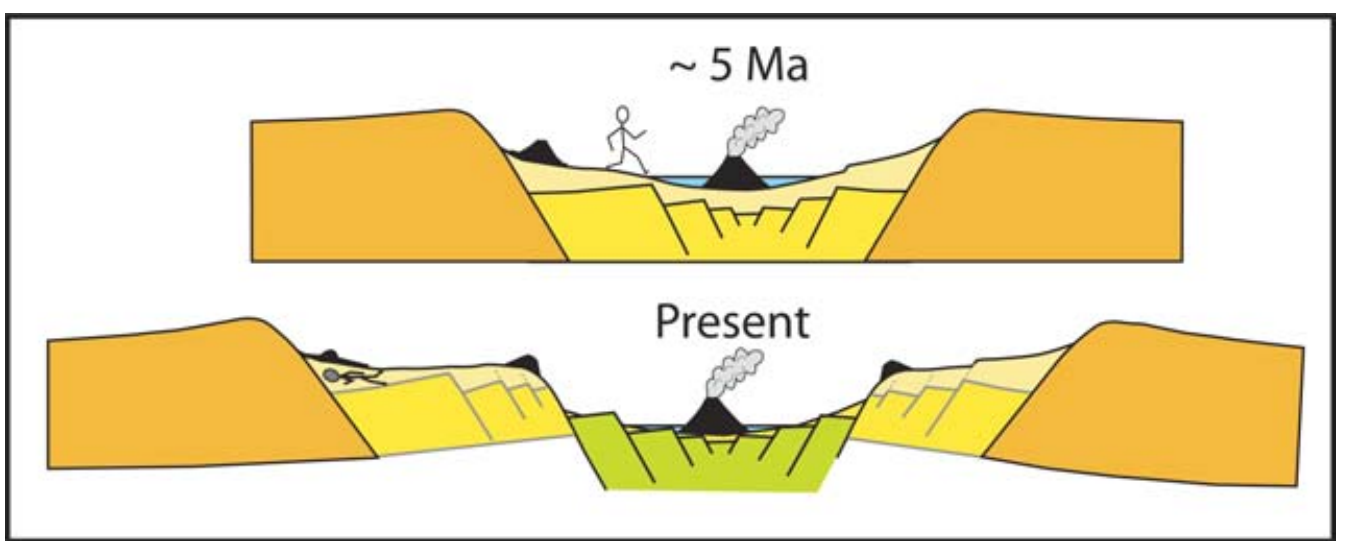

Figure 4. Change in the location of sites with progressive rifting. The environment where fossils were deposited in most African sites was in the bottom of the active rift (upper diagram). Activity has since created a new rift axis uplifting the older axis (lower diagram). Human figures are not to scale.

less dependent on trees as a protective retreat, better able to range widely over varying environments and more effective carnivores.

Beyond the southern limit of the Rift lies the Transvaal region of South Africa. This region has produced early dated material, and appears to be part of the geographical zone within which some of the earliest species of hominins evolved, or to which they rapidly dispersed. Yet it is not subject to the extensional and volcanic activity typical of the African Rift. It is, however, a region of active tectonics resulting from the long-term uplift of the South African region associated with the stability of the African plate, as noted above, and is subjected to distinctive tectonic controls on topography and water supply. Repeated faulting results in localisation and rejuvenation of perennial water supplies and thermal springs. In elevated limestone terrain, karstic processes produce localised topographic complexity and caves with advantages of protection and tactical advantage (Chris Hartnady pers comm.; Kuman 1998). In key respects, then, the region shows similarities to the Rift in terms of long-term tectonic activity and topographic complexity. But the contrasts suggest that the distinctive features of the Rift may be a subset of the more general phenomenon of tectonically created topographic 'roughness'. We shall return to this point after more detailed consideration of Rift landscapes.

\section{Archaeological implications}

A schematic cross-section through the Rift shows how the morphology commonly evolves over long periods of time and alters topographic features at a local scale (Figure 4). The rift is shown as a symmetrical feature although asymmetry is more common. As the rift widens, the original valley floor gradually becomes uplifted and rotated and new valley floor appears. In time, the rift flanks show a step-like effect, with the highest and oldest features showing less tectonic activity and a topography more smoothed by long-term erosion (Figure 5). The present-day locations of Plio-Pleistocene archaeological sites and fossils, and the features of the immediately surrounding landscape visible today, are often a quite misleading guide to 


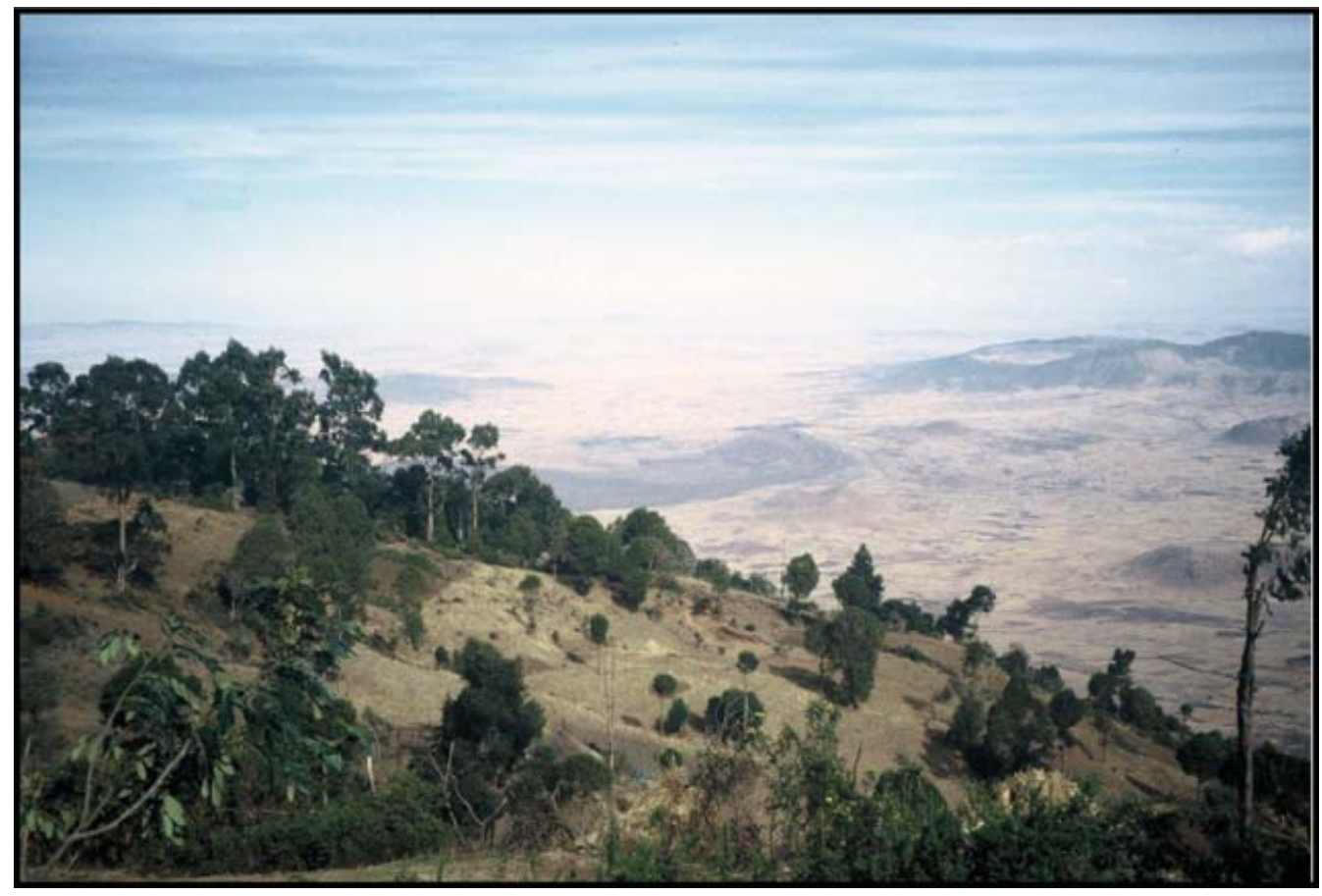

Figure 5. A view looking east into the Ethiopian Rift east of Addis Ababa. This area is now to the west of the active rift and is now almost inactive. However, features identified in Figure 2 can be seen but have been smoothed by erosion.

the situation at the time when the sites were active. The Hadar site is now perched on the uplifted flank of the Ethiopian rift whereas 3 million years ago it would have been located on or close to the active rift floor. The Olduvai Gorge shows a similar geological history, with early Pleistocene sites originally formed on the active rift floor and in lake-edge locations that have been subsequently uplifted and deeply incised by tectonic movement and river down-cutting.

Uplift and erosion have well-known implications for the exposure and visibility of fossil and archaeological localities. It is the erosion of the Awash River, cutting back into earlier deposits, that has revealed the hominin bones at Hadar, for example. However, these same processes also make it more difficult to reconstruct the original detail of the local topography. Small-scale features such as the edges of lava flows and river-terrace risers a few metres high, though highly significant as barriers to movement, may be removed by subsequent erosion or buried by sediment, or survive only as fragments. It is very difficult if not impossible to reconstruct their distribution around an ancient site by working from a limited number of sections into the underlying strata. As is indicated in Figure 2, the underlying strata that result from ongoing processes at the surface are discontinuous and form no easily discernible or coherent pattern. Were it not for studies of active volcanic landscapes that are the modern equivalent of ancient ones, we would have little idea of the small-scale features associated with the ancient landscape. Nor would we know what to look for, or what might be missing in conventional methods of landscape reconstruction based on correlations of 
dateable features and sections from a limited number of stratigraphic windows (Bailey et al. 2000).

Few attempts have been made to incorporate tectonics into palaeogeographical reconstructions of early hominin sites and their associated landscapes. Tectonic processes, if they are not ignored completely at this local scale, are usually treated as background events, as occasional disruption of sedimentary processes, or as sources of volcanic raw material for stone tools. There are very real difficulties of reconstructing the original landscape morphology in active tectonic settings, and we do not minimise them.

One problem is that reconstructions around sites of archaeological significance typically begin with the sediments that enclose the archaeological and fossil material, and work outwards by correlation of stratigraphic intervals, sedimentary features and palaeosols to progressively larger areas of the surrounding basin (e.g. Brown \& Feibel 1991; Feibel et al. 1991; Potts et al. 1999; Rogers et al. 1994). This is a necessary and important starting point in a context where radical geomorphological change induced by tectonic processes has occurred since the time of deposition. However, the requirement for dateable material leads to a focus on the sedimentary infill of the basin rather than to other critical topographic features such as lava fields, faults, localised barriers to movement, and blocks of land that have been tilted and rotated. Moreover, the need for stratigraphic correlation limits the area over which reconstructions can be extended before they encounter discontinuities between one sedimentary basin and the next. The high spatial and temporal resolution of such analyses results in a reconstruction over areas of landscape and spans of time that may be too small to allow an appreciation of their significance in a larger geographical or temporal context.

Conversely, inferring tectonic processes from detailed mapping of local surface features can be highly misleading, and interpretation tends to operate over much larger areas in a process of working down from the large scale to the local level. Only over the past decade or so, with the widespread availability of satellite imagery and more recently digital elevation data, has it become possible to combine the large-scale mapping of fault lines and other tectonic features with local field data and dating control. This has revolutionised our ability to understand the mechanics of continental deformation and its relationship to surface processes (e.g. Hubert-Ferrari et al. 2002a; Tapponnier et al. 2001, and references therein). So far, this approach has not yet been applied in detail to the African Rift, with the exception of the Afar (e.g. Hubert-Ferrari et al. 2002b; Manighetti et al. 2001, and references therein), nor has it been combined with analysis of local areas with archaeological and fossil material.

Another problem is the status of sites and the degree to which they can be considered representative of all the activities of early hominin groups. There are good reasons for suspecting that the known sites are biased by factors of differential preservation and visibility and are less than representative of all the locations of significance to early human activity in the surrounding area. The sites we know about are places where artefacts were discarded, and parts of animal carcasses and human corpses abandoned. Many if not most such sites are palimpsests representing a succession of unrelated episodes of deposition that bear no relationship to residential sites as that term might commonly be used in ethnographic studies of hunters and gatherers (cf. Binford 1981; Stern 1993, 1994). Some were most probably ephemeral scavenging locations used for perhaps as a little as a few days, but we do not 
know whether they were also used as sleeping areas or for more prolonged periods. Most were probably not used for central place foraging or home bases as originally proposed by Isaac (1978). The great majority occur in lacustrine or alluvial basins because this is where discarded material is most likely to be covered by sediment and preserved for future discovery. While these sites give a general indication of preferred areas of activity, classic techniques of site catchment analysis that assume a residential site at the centre of its exploitation territory and work outwards from archaeological find spots to the wider landscape, on the assumption that resources in closest proximity are of greatest importance, are likely to be misleading (Bailey 2005). Working downwards in scale from the regional distribution of resources to the local scale is considered a preferable analytical strategy in such circumstances (Sturdy et al. 1997; Flannery 1976; Foley 1977).

These difficulties are highlighted by an objection that is commonly raised to the tectonic hypothesis, namely that early sites in the African Rift are located in smooth alluvial plains. Undoubtedly influential here are the Lake Turkana sites. The majority of these are on the edges of stream channels in the alluvial plain of the ancient river basin or on the margins of the subsequently formed lake (Brown \& Feibel 1991; Brown \& McDougall 1993; Feibel \& Brown 1993; Feibel et al. 1991; Rogers et al. 1994). Palaeotopographical reconstructions typically show an area of some 10 hectares around a site, with open savannah vegetation, scattered Acacia trees and denser stands of larger trees along river courses, as at the FxJj50 site (Bunn et al. 1980). The relationship of that area to the total that might have been used can be gauged from figures for hominin home ranges. Antón et al. (2002), using analogies with modern apes and hunter gatherers, suggest figures for Australopithecines and early Homo ranging from 38 hectares to 452 hectares, depending on body size and diet, but note that increased dependence on meat might lead to use of much larger areas. Foley (1987: 140 ), citing evidence of importation of raw materials from non-local sources, gives figures of 1256 hectares for the Turkana Basin and 45203 hectares for Olduvai. In both areas, analysis of site distributions in relation to sources of raw materials suggests changes in the organisation of land use by Homo erectus and progressive enlargement of the areas over which they foraged (Blumenschine \& Peters 1998; Potts et al. 1999; Rogers et al. 1994). Areas typically shown in detailed palaeotopographical reconstructions of site surroundings might thus represent anything from as much as 26 per cent of the hypothetical home range to as little as 2 per cent. These percentages might be even lower if we take into account areas within the lifetime range less frequently visited but critical to long-term survival, and are some indication of the larger areas that should be analysed to place local sites into wider perspective. In other words, even though there are extensive areas of flood plain in the Turkana Basin, it is an area that has also been subject to repeated volconic activity and tectonic movement over a long period, with numerous faults and extensive areas of lava flows within daily foraging range of many sites.

\section{Tectonics and human dispersal beyond the African Rift}

When we turn to tectonically active areas in other parts of Africa, or to regions outside Africa, the dominant style of tectonics is usually contractional, with convergence of continental plates and compression and uplift associated with reverse faulting, or strike-slip motion 


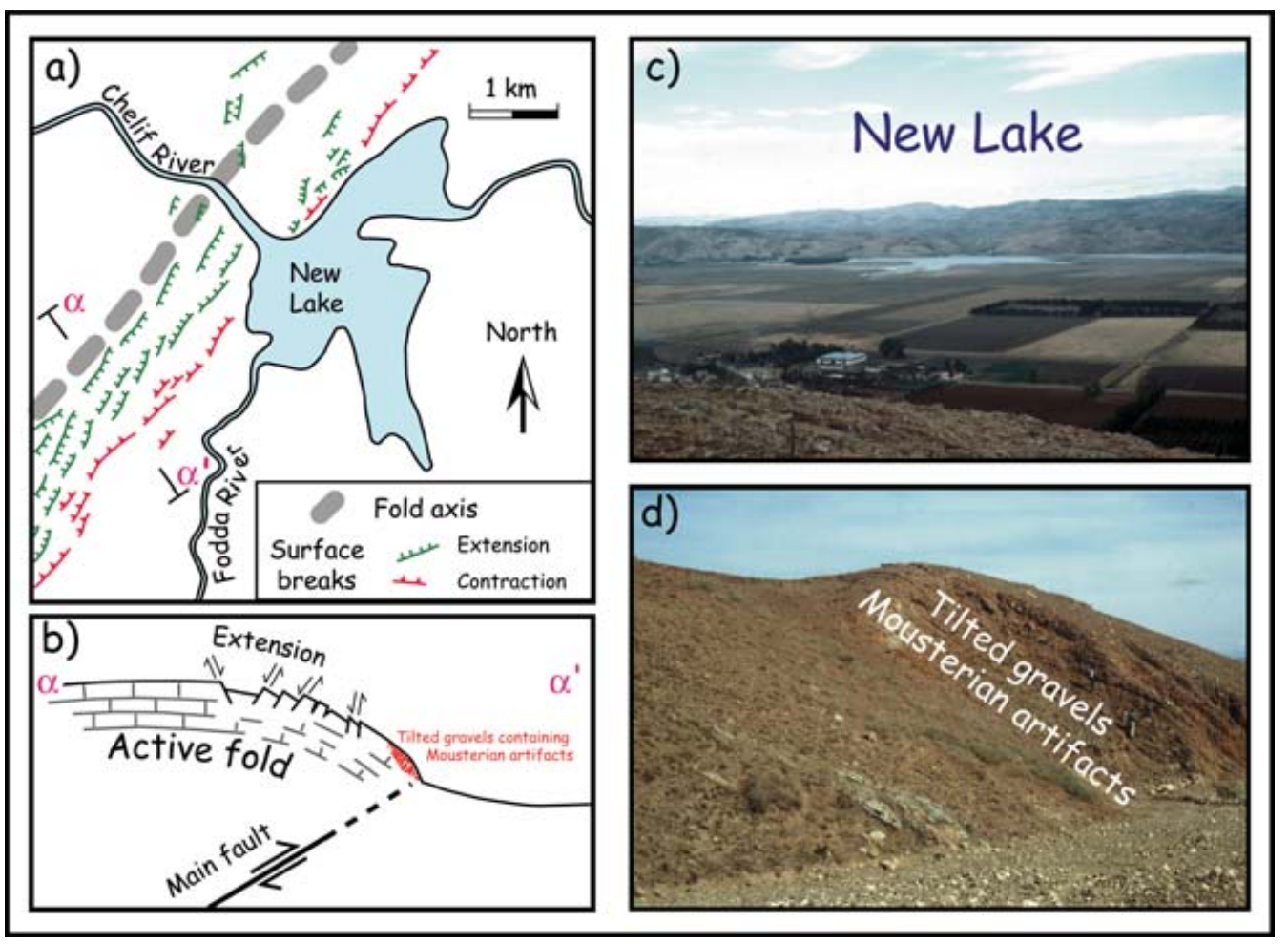

Figure 6. Faulting and lake formation in the El Asnam region of Algeria. (a) Map of the region where a new lake was formed as a result of fold uplift during the El Asnam earthquake. (b) Cross section along the line $\alpha-\alpha$ ' in Figure 6(a). Gravels tilted to nearly vertical by repeated past earthquakes occur along the base of the anticline and contain Mousterian artefacts. (c) $A$ photograph of the lake and anticline viewed to the NW from near the SE corner of the map in Figure 6(a). (d) Tilted gravels at the base of the anticline.

in which plates slide past each other, resulting in long linear valleys with complex alluvial histories, while any extension is associated with less widespread volcanism. The question arises, then, as to the nature of these tectonic environments and the extent to which their distribution may have constrained or facilitated wider patterns of human dispersal.

In the contractional environment of north-west Africa, observations of the 1984 earthquake of El Asnam in Algeria demonstrated a key relationship between a major earthquake, the growth of folding at the surface and the tectonic control of the water table. The earthquake resulted in vertical displacement of about $3 \mathrm{~m}$ on a partially buried fault over a distance of 30km (King \& Vita-Finzi 1981; King \& Yielding 1984). Uplift associated with the faulting and folding across the course of the Chelif River impeded water flow and rejuvenated a lake in the basin upstream of the fold axis that had dried out in preceding decades (Figure 6). The fold axis represents the cumulative uplift of successive earthquake events over many millennia, and tilted gravels within it contain Palaeolithic artefacts, demonstrating the attractions of the area for prehistoric settlement. Similar observations in other areas of the Mediterranean, notably in north-west Greece, a region of strike-slip and contractional tectonics, demonstrate the influence of tectonic controls on Palaeolithic settlement. Archaeological sites are associated with tectonically 
created and maintained local basins of fertility, which conferred a degree of insulation from the impact of climatic changes and especially late glacial aridity, and with topographic barriers that allowed control of mobile prey species and provided secluded locations where human groups could monitor animal migration routes without disturbing the animals (Bailey et al. 1993; King \& Bailey 1985; King et al. 1993, 1994, 1997; Sturdy et al. 1997).

Outside Africa, the Red Sea coasts would have offered similar environments to the East African Rift and volcanic activity extending nearly to historic times occurs extensively on the Arabian side, although faulting is rare. The 'Syrio-Jordan Rift' extending from the Gulf of Aqaba to eastern Turkey is mainly a strike-slip feature although south of Mount Lebanon significant opening and normal faulting is prevalent. Substantial volcanism over the last 2 million years has also occurred over large portions of the system, particularly in the region of the present Lake Kinneret (Sneh et al. 1998).

Between Northern Israel and Syria strike-slip motion is accommodated along faults (mainly the Yamouneh fault), which are angled at about $20^{\circ}$ to the overall direction of the 'Syrio-Jordan Rift'. This geometry results in contraction, which over the last 10 million years has created Mount Lebanon (Freund 1965; Garfunkel et al. 1981). While volcanic activity is almost absent in Lebanon, the uplift has created spectacular topography and a diverse range of environments. The present day complexity has been enhanced by features resulting from glaciers that extended almost to the sea during glacial maxima. The Bekka valley and the coastal regions have in historical times provided secure refuge for humans fleeing persecution (Salabi 1988) and the same features may have proved important for prehistoric hominins.

In Turkey the east Anatolian fault extends to the region of Lake Van in the Caucasus. To the east, morphology resulting from contractional and strike-slip activity extends through Iran to the Himalayas. To the west, the North Anatolia fault runs to reach the Aegean at Gallipoli at the western end of the Sea of Marmara. These major features together with associated minor structures provide tectonically complex environments with many of the characteristics we have described for the African Rift. In south-east Asia, subduction systems are associated with volcanism and with tectonic activity more intense than in Africa.

Some of the earliest and best dated evidence of early human activity outside East and South Africa (summarised in Bar-Yosef 1998; Bar-Yosef \& Belfer-Cohen 2001; Dennell 2003; Rolland 1998) is clearly in tectonically active regions, in the active contractional zone of north-west Africa at 1.8 million years at sites such as Ain Hanech (Raynal et al. 2001), at Ubeidiyah and Erq El Ahmar at $\sim 1.4$ million and $\sim 1.8$ million years respectively (Ron $\&$ Levi 2001), associated with the Jordan Rift and its complex volcanic, alluvial and lacustrine history, and at Dmanisi in the southern Caucasus (Gabunia et al. 2000; Lordkipanidze et al. 2000), at $\sim 1.7$ million years, in a contractional tectonic environment with evidence of lake environments and volcanic activity. Hominin finds from the Sangiran dome of Indonesia are of equivalent date, $\sim 1.8$ million years (Swisher et al. 1994), and are associated with the complex tectonics and intense volcanism of the Java subduction system. Whether there was early settlement in Europe at a similarly early date remains disputed.

The site of Ubeidiyah is associated with lake-edge topography and extensive lava flows (Figure 7) and would have offered a familiar environment to early hominins adapted to the African Rift. The site of Dmanisi is associated with similar features. These sites have some 


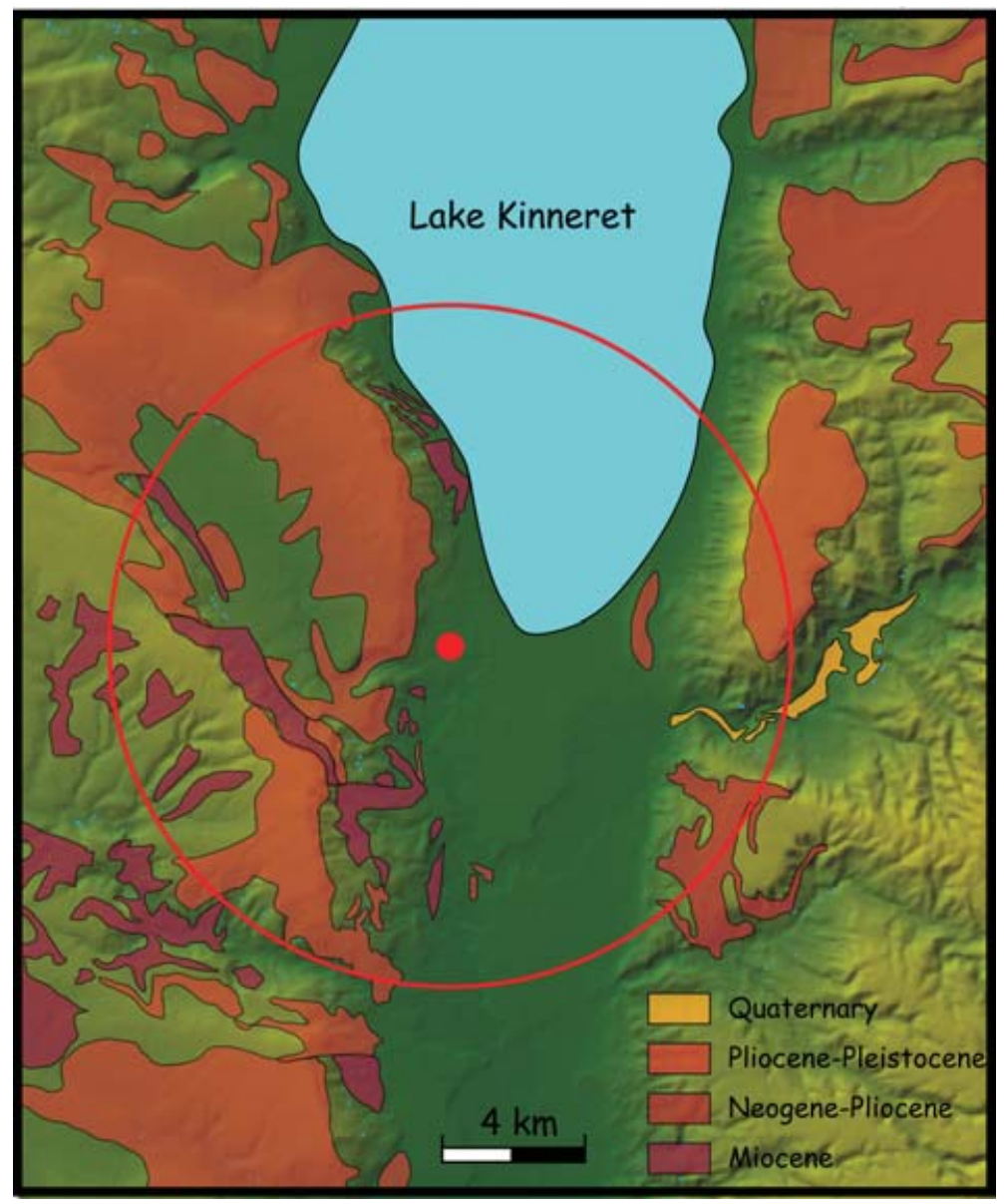

Figure 7. The region around the Ubeidiyah site (red spot). The red circle has a radius of $10 \mathrm{~km}$. Basalt lava flows are shown with ages taken from Sneh et al. 1998.

of the earliest, best documented and most persistent evidence of human occupation outside Africa, and we consider it significant that they not only have local environments dominated by tectonic and volcanic topography, but that they also lie on a potential pathway of dispersal that provides a virtually unbroken series of similar tectonic environments linking the Afar and the southern Caucasus.

\section{Topographic roughness and human dispersal}

The features we have identified exist on a range of scales and cannot be characterised in a simple way. One useful proxy measure of tectonic activity is topographic 'roughness', and it is now possible to measure this in a systematic way on a continental scale through the manipulation of digital elevation data. In Figure 8 we present three versions of digital data for Africa, Europe and Asia, together with the oldest hominin sites outside Africa. 
Figure 8 a shows the topography, with red indicating high altitude and blue low altitude. In Figure 8 b, areas of rough topography are identified, but are de-emphasised at high altitude on the assumption that early hominins could not exploit cold conditions. In Figure 8c, areas at high latitude are also excluded on the assumption that these areas would have been inaccessible to the earliest human populations because of extreme climatic conditions. Sites can be seen to correlate with areas of rough topography.

The roughness maps provide a measure of tectonically active environments together with some simple constraints to eliminate climatic extremes. This is an admittedly simplified approach, but one which allows a systematic overview over large areas, a proxy indication of the areas most favourable to human settlement and the most obvious pathways for dispersal.

For the pathway out of Africa into Eurasia, the Nile Valley is often assumed to be the most obvious route, funnelling movements through the narrow bottleneck of the Sinai Peninsula and into the Levantine corridor. However, with the exception of the undated site of Abassieh, there is no evidence of Lower Pleistocene hominin activity in Lower Egypt (Vermeersch 2001). The roughness maps suggest that a more obvious route is from the Afar and along the Red Sea margins. The Red Sea is itself a rift formation, and on the Arabian side volcanic activity with extensive lava flows of Pliocene and Pleistocene date has created local environments with familiar attractions of localised fertility and complex topography. The presence of stone tools of Acheulean and Oldowan type in Saudi Arabia and the Yemen, though mostly undated as yet by radiometric means, reinforces the possibility of early occupation (Petraglia 2003; Whalen \& Fritz 2004).

The roughness maps also clearly bring out the northerly route out of the Red Sea into the Syrio-Jordan Rift and the virtually continuous line of tectonically active environments extending along the East Anatolian fault as far as the southern Caucasus, westwards along the North Anatolian fault to the tectonically active southern peninsulas of Europe, and eastwards to the tectonically active environments of the Iran/Iraq border leading on to the foothills of the Himalayas and thence southwards to the peninsulas and archipelagos of southern Asia.

A number of indirect considerations have recently highlighted the attractions of a southerly dispersal route from Africa via the Arabian coastline to south-east Asia, at least for anatomically modern humans and perhaps also for earlier dispersals (Macaulay et al. 2005; Mithen \& Reed 2002; Stringer 2000; Walters et al. 2000). The southern margin of the Arabian Peninsula certainly provides a shorter pathway to the Indian Subcontinent than the alternative to the north and one that appears relatively attractive in topographic terms (Figure 8c), although the roughness map for these regions must necessarily remain incomplete without the incorporation of the now submerged topography that would have been available during periods of lowered sea level.

A critical factor for this pathway is the barrier posed by the Bab el Mandeb Straits, which requires a sea crossing of $20 \mathrm{~km}$ between Africa and the south-west corner of the Arabian Peninsula. However, at lowered sea levels the Straits would have represented a much narrower waterway, although one that was probably never bridged by dry land during the maximum sea level regressions of the earlier Pleistocene (Lambeck pers. comm.). Even so, lowered sea levels would have produced a narrow channel as little as $5 \mathrm{~km}$ wide extending for over $100 \mathrm{~km}$, scarcely more of a barrier than a large river, and the availability of littoral and marine resources may have been an added attraction (Flemming et al. 2003; Walters et al. 2000). 


\section{Tectonics and human evolution}
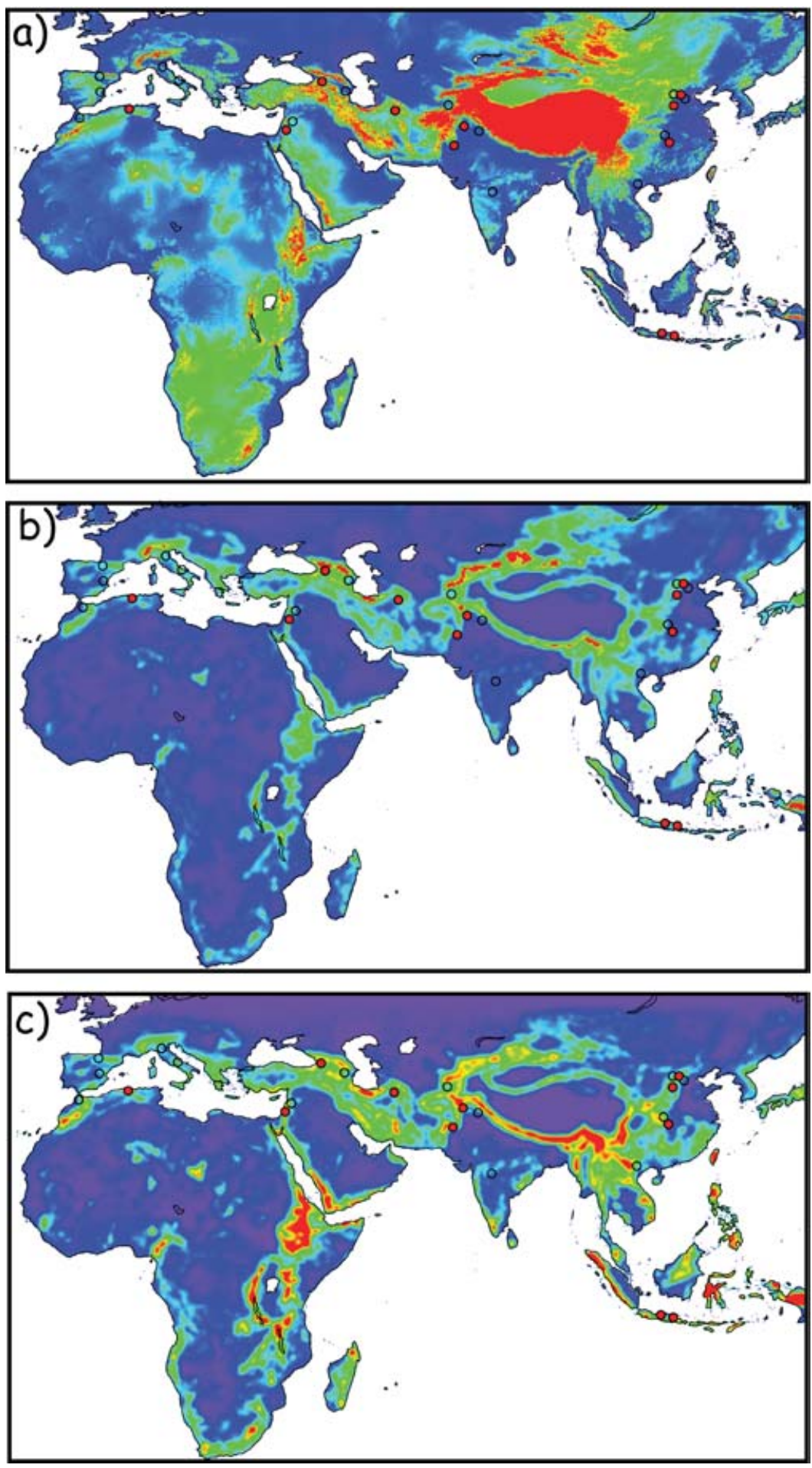

Figure 8. For legend see facing page. 
North-west Africa stands out as a rather isolated island within the African continent. Indeed, from the point of view of complex topography on a large scale, the most obvious pathway leading from East Africa to north-west Africa appears to lie along the eastern and northern coastal regions of the Mediterranean, rather than across the Sahara or around the southern shore of the Mediterranean (Figure 8c). However, the case for crossing the Strait of Gibraltar at an early date, though plausible, remains ambiguous, and there is a serious lack of early-dated sites between southern Spain in the west and the southern Caucasus and the Levant in the east (Straus 2001).

Hominin dispersal out of Africa seems on current evidence to have been delayed until the emergence of Homo erectus, suggesting either some physical or ecological barrier to an earlier dispersal or lack of appropriate abilities in earlier hominin populations. Amongst the various candidates for such constraining influence are climatic and geographical barriers, lack of critical technological or social skills, competitive relationships with other carnivores and scavengers, differential resistance to disease or smaller home ranges and more limited powers of dispersal (Antón et al. 2002; Bar-Yosef 1998; Bar-Yosef \& Belfer-Cohen 2001; Dennell 1998; Gamble 1993; Mithen \& Reed 2002; Rolland 1998; Turner 1992, 1999). Our emphasis on tectonics raises the question of the ways in which contractional and strike-slip environments outside Africa may have facilitated or impeded human dispersal.

These sorts of environments produce a complex topography of barriers and basins that trap water and sediment, providing concentrations of local fertility and resource diversity, and opportunities for the strategic observation or control of mobile herd animals, not dissimilar to the African Rift. But they lack the distinctive features associated with extensive lava flows and rifting. Numerous small faults give way to less numerous larger features, and abrupt features such as those shown in Figure $3 \mathrm{~d}$ are less common. Absence of these features appears to have been no disincentive to early occupation in South Africa, so there is no reason why they should have been a disincentive to dispersal elsewhere. However, Ben-Avraham \& Hough (2003) have noted an additional factor that may be relevant here. The Syrio-Jordan Rift extending north from the Gulf of Aqaba at the head of the Red Sea and along the Wadi Araba to the Dead Sea, provides an attractive stepping stone out of Africa, but it did not come into existence until some time between 3 and 2 million years ago. Hence the absence of tectonic environments on this critical pathway out of Africa may have been sufficient to impede dispersal at an earlier date.

\footnotetext{
Figure 8. Digital maps of Africa, Europe and Asia derived from SRTM 30 data (resolution of c. 800 metres). In each figure, filled red circles indicate the earliest evidence of hominins outside Africa and open circles the next earliest evidence, following Dennell (2003), with additions, notably the recently reported site of Majuangou (Zhu et al. 2004). (a) Elevation map, with red indicating high elevation and blue low elevation. (b) Roughness map corrected for altitude. The map is calculated by the following steps. (1) The SRTM 30 data are smoothed using a $21 \times 21$ gaussian filter. (2) This is subtracted from the original data and the result squared to remove negative values. This provides a measure of roughness at kilometric scales and a proxy for the smaller scales discussed in the text. (3) Since rough terrain at high altitude (e.g. Tibet) would not have provided hominin habitats, these regions are de-emphasised by dividing the result of step 2 by the smoothed topography from step 1 . In the final figure, red indicates rough terrain at low altitude and blue indicates either smooth terrain or rough terrain at high altitude. (c) Roughness map corrected for altitude and latitude. The data are subject to the same three operations as are performed for figure $8(b)$. In a further step, the data are divided by the square root of the cosine of latitude. This de-emphasises regions such as Mongolia that would have been too climatically challenging for early occupation.
} 
Finally, we should note that the roughness maps highlight areas of potential attractiveness to early human settlement but which lack relevant evidence, notably in the western Rift and areas further west in Africa, and which might thus repay closer investigation for relevant evidence or for factors other than geological ones that may have deterred early human occupation.

\section{Conclusion}

The active tectonics of the African Rift creates features that we believe are essential to understanding the ecological basis of human evolution. Tectonics provides the physical basis for a diversified environment with varied food resources and abundant water supplies: the environmental mosaic so often referred to as a primary advantage of the African Rift. It offers physical protection in the form of cliffs, lava flows and topographic enclosures, and hence small-scale topographic complexity in which a relatively defenceless species can find protection from predators. It creates a larger scale topographic complexity of fault scarps, folds, lava fields and natural traps, which can provide tactical advantage in pursuit of prey. Finally, it results in geologically unstable conditions that lead to greater variability in the precise configuration of topographic variables in time and space, and thus sharpens the selective pressures in favour of multiple speciation and/or adaptable behaviour. These are distinctive and unique attractions of the African Rift and ones that are the product of its unusual tectonic history. Tectonic environments outside the African Rift provide comparable if less distinctive features, and the opportunity afforded by digital elevation data to map their distribution over large areas offers predictions about likely pathways for human dispersal more widely within and beyond Africa.

We have noted the problems that stand in the way of testing tectonic hypotheses at the local scale and suggested the need to combine a newer generation of techniques of tectonic mapping and interpretation with established techniques of palaeogeographic reconstruction. In the absence of such work, it would be premature to be more specific about the relationship between tectonics and evolutionary events, though we suggest that topographic complexity is likely to have been a more critical agent of selection as meat became a more important food resource and the capacity for wide-ranging mobility more pressing.

It can, of course, be objected that the large-scale patterns of association that we have identified are coincidental and merely reflect geological conditions conducive to the preservation and exposure of archaeological evidence. We do not minimise those effects and have discussed examples earlier of ways in which landscape deformation can differentially obscure, destroy or expose archaeological material. However, by commonly held consensus and the convergence of many independent lines of evidence, the African Rift (sensu lato) is held to be a key zone for the successful emergence and expansion of the genus Homo, and probably also for our own species Homo sapiens sapiens. It seems unlikely on current evidence that the privileged position of the African Rift in this respect can be dismissed as mere coincidence resulting from differential visibility of evidence.

Our emphasis here is on the impact of tectonics at all scales of analysis but especially at smaller geographical scales, and its creative role in sustaining local environmental conditions attractive to human settlement and dispersal, rather than the destructive effects resulting from episodic disruption. The African Rift stands out as being distinctive at every scale. 


\section{Geoffrey King \& Geoff Bailey}

Above all, we emphasise that this tectonic perspective requires us to think of change in the physical landscape as a continuous and dynamic process operating at many different scales with far-reaching ecological ramifications, even in seemingly placid regions and especially as we move on to longer time scales and into tectonically more active regions. Attempts to incorporate into a study of human evolution the physical environment, which treat it as a static fixture, or a static fixture subject to occasional and episodic change, are missing a vital piece of the larger picture.

\section{Acknowledgements}

We acknowledge financial support from NERC, through its EFCHED programme (Environmental Factors in Human Evolution and Dispersal), the British Academy, INSU-CNRS, and the Leverhulme Trust through its Major Research Fellowship scheme. We thank Vincent Courtillot for his enthusiastic encouragement and discussion of ideas, Kurt Lambeck and three anonymous assessors for their critical comments, which have helped in the refinement of our argument and the elimination of errors, and Brigitte Senut and Martin Pickford for information on African site locations. The ideas expressed here are the result of fruitful interaction over a long period, and while King is primarily responsible for the geological input, and Bailey for the archaeological, we are equally responsible for the resulting integration and any remaining deficiencies. This paper is IPGP contribution number 2112 and INSU contribution number 391.

\section{References}

Aiello, L.C. \& P. Wheeler. 1995. The expensive tissue hypothesis: the brain and the digestive system in human and primate evolution. Current Anthropology 36 (2): 199-221.

Anderson, D.L. 1982. Hotspots, polar wander, Mesozoic convection, and the geoid. Nature 297: 391-3.

Antón, S.C., W.R. Leonard \& M.L. Robertson. 2002. An ecomorphological model of the initial hominid dispersal from Africa. Journal of Human Evolution 43: 773-85.

Armijo, R., B. Meyer, G.C.P. King, A. Rigo \& D. Papanastassiou. 1996. Quaternary evolution of the Corinth Rift and its implications for the Late Cenozoic evolution of the Aegean. Geophysical Journal International 126 (1): 1-53.

Bailey, G.N., G.C.P. King \& D.A. STurdy. 1993. Active tectonics and land-use strategies: a Palaeolithic example from northwest Greece. Antiquity 67: 292-312.

Bailey, G., G. King \& I. Manighetti. 2000. Tectonics, volcanism, landscape structure and human evolution in the African Rift, in G.N. Bailey, R. Charles \& N. Winder (ed.) Human Ecodynamics: Proceedings of the Association for Environmental Archaeology Conference 1998 held at the University of Newcastle upon Tyne: 31-46. Oxford: Oxbow.

BAILEY, G.N. 2005. Site catchment analysis, in C. Renfrew \& P. Bahn (ed.) Archaeology: the Key Concepts: 230-5. London: Routledge.
BAR-Yosef, O. 1998. Early colonizations and cultural continuities in the Lower Palaeolithic of western Asia, in M.D. Petraglia \& R. Korisettar (ed.) Early Human Behaviour in Global Context: 221-79. London: Routledge.

Bar-Yosef, O. \& A. Belfer-Cohen. 2001. From Africa to Eurasia - early dispersals, in L.G. Straus \& O. Bar-Yosef (ed.) Out of Africa in the Pleistocene: an introduction. Quaternary International 75: 19-28.

Ben-Avraham, Z. \& S. Hough. 2003. Promised Land. Natural History, October: 44-9.

Binford, L.R. 1981. Bones: Ancient Men and Modern Myths. London \& New York: Academic.

Blumenschine, R.J. \& C.R. Peters. 1998. Archaeological predictions for hominid land use in the paleo-Olduvai Basin, Tanzania, during lowermost Bed II times. Journal of Human Evolution 34: 565-607.

Brown, F.H. \& C.S. Feibel. 1991. Stratigraphy, depositional environments, and palaeogeography of the Koobi Fora formation, in J.M. Harris (ed.) Koobi Fora Research Project, Volume 3, The Fossil Ungulates: Geology, Fossil Artiodactyls, and Palaeoenvironments: 1-30. Oxford: Clarendon.

Brown, F.H. \& I. McDougall. 1993. Geologic setting and age, in A. Walker \& R. Leakey (ed.) The Nariokotome Homo Erectus Skeleton: 9-20. Berlin: Springer-Verlag.

Brunet, M., F. Guy, D. Pilbeam, H.T. Mackaye, A. Likius, A. Djimboumalbaye etal. 2002. A new hominid from the Upper Miocene of Chad, Central Africa. Nature 418: 145-51. 


\section{Tectonics and human evolution}

Bunn, H.T. 1994. Early Pleistocene hominid foraging strategies along the ancestral Omo River at Koobi Fora, Kenya. Journal of Human Evolution 27: 247-66.

Bunn, H., J.W.K. Harris, G. Isaac, Z. Kaufulu, E. Kroll, K. Schick, N. Toth \& A.K. Behrensmeyer. 1980. FxJj50: an early Pleistocene site in northern Kenya. World Archaeology 12: 109-36.

Burke, K. 1996. The African plate. South African Journal of Geology 99 (4): 341-410.

Cachel, S. \& J.W.K. Harris. 1998. The lifeways of Homo erectus inferred from archaeology and evolutionary ecology: a perspective from East Africa, in M.D. Petraglia \& R. Korisettar (ed.) Early Human Behaviour in Global Context: 108-32. London: Routledge.

Clutton-Brock, J. 1999. 2nd ed. A Natural History of Domesticated Mammals. Cambridge: Cambridge University Press.

Coppens, Y. 1994. East side story: the origin of humankind. Scientific American 270: 62-9.

Davidson, J.P., W.E. Reed \& P.M. Davis. 2002. Exploring Earth. New Jersey: Prentice Hall.

Delson, E., I. Tattersall, J.A. Van Couvering \& A.S. BRooks (ed.). 2000. 2nd ed. Encyclopedia of Human Evolution and Prehistory. New York: Garland.

Dennell, R.W. 1998. Grasslands, tool-making and the hominid colonization of southern Asia: a reconsideration, in M.D. Petraglia \& R. Korisettar (ed.) Early Human Behaviour in Global Context: 280-303. London: Routledge.

-2003. Dispersal and colonisation, long and short chronologies: how continuous is the Early Pleistocene record for hominids outside East Africa. Journal of Human Evolution 45: 421-40.

Dixon, E.J. 2001. Human colonization of the Americas: timing, technology and process. Quaternary Science Reviews 20: 277-99.

ErLandson, J.M. 2001. The archaeology of aquatic adaptations: paradigms for a new millennium. Journal of Archaeological Research 9: 287-350.

Feibel, C.S. \& F.H. Brown. 1993. Microstratigraphy and paleoenvironments, in A. Walker \& R. Leakey (ed.) The Nariokotome Homo Erectus Skeleton: 21-39. Berlin: Springer-Verlag.

Feibel, C.S., J.M. Harris \& F.H. Brown. 1991. Palaeoenvironmental context for the late Neogene of the Turkana Basin, in J.M. Harris (ed.) Koobi Fora Research Project, Volume 3, The Fossil Ungulates: Geology, Fossil Artiodactyls, and Palaeoenvironments: 321-46. Oxford: Clarendon.

Flannery, K.V. (ed.). 1976. The Early MesoAmerican Village. London \& New York: Academic.
Flemming, N., G. Bailey, V. Courtillot, G. King, K. Lambeck, F. Ryerson \& C. Vita-Finzi. 2003. Coastal and marine palaeo-environments and human dispersal points across the Africa-Eurasia boundary, in C.A. Brebbia \& T. Gambin (ed.) The Maritime and Underwater Heritage: 61-74.

Southampton: Wessex Institute of Technology Press.

Foley, R. 1977. Space and energy: a method for analysing habitat value and utilization in relation to archaeological sites, in D.L. Clarke (ed.) Spatial Archaeology: 163-87. London \& NY: Academic Press.

-1987. Another Unique Species: Patterns in Human Evolutionary Ecology. Harlow: Longman.

-1995. Humans before Humanity. Oxford: Blackwell.

Freund, R. 1965. A model of the structural development of Israel and adjacent areas since Upper Cretaceous times. Geology Magazine 102: 189-205.

Gabunia, L., A. Vekua \& D. Lordkipanidze. 2000. The environmental contexts of early human occupation of Georgia (Transcaucasia). Journal of Human Evolution 38: 785-802.

Gamble, C. 1993. Timewalkers: The Prehistory of Global Colonization. London: Sutton.

-1998. Concluding remarks: archaeology's fifth big question, in M.D. Petraglia \& R. Korisettar (ed.) Early Human Behaviour in Global Context: 451-68. London: Routledge.

Garfunkel, Z., I. Zak \& R. Freund. 1981. Active faulting in the Dead Sea Rift. Tectonophysics 80: $1-26$.

Hubert-Ferrari, A., R. Armijo, G.C.P. King, B. Meyer \& A. Barka. 2002a. Morphology, displacement and slip rates along the North Anatolian Fault, Turkey. Journal of Geophysical Research 107,0,10.1029/2001JB000393, 2002.

Hubert-Ferrari, A., G.C.P. King, I. Manighetti, R. Armijo, B. Meyer \& P. Tapponnier. 2002b. Long-term elasticity in the continental lithosphere; modelling the Aden Ridge propagation and the Anatolian extrusion process. Geophysical Journal International 15: 111-32.

IsAac, G.L. 1978. The food-sharing behaviour of protohuman hominids. Scientific American 238: 90-108.

Keegan, J. 1993. A History of Warfare. London: Random House.

King, G.C.P. \& G.N. Bailey. 1985. The palaeoenvironment of some archaeological sites in Greece: the influence of accumulated uplift in a seismically active region. Proceedings of the Prehistoric Society 51: 273-82. 


\section{Geoffrey King \& Geoff Bailey}

KING, G.C.P. \& M. Ellis. 1990. The origin of large local uplift in extensional regions. Nature 348: 20-7.

KInG, G.C.P. \& C. Vita-Finzi. 1981. Active folding in the Algerian earthquake of 10 October, 1980. Nature 292: 22-6.

KING, G. \& G. Yielding. 1984. The evolution of a thrust fault system: processes of rupture initiation, propagation and termination in the $1980 \mathrm{El} \mathrm{Asnam}$ (Algeria) earthquake. Geophysical Journal of the Royal Astronomical Society 77: 915-33.

King, G., G. Bailey \& D. Sturdy. 1994. Active tectonics, complex topography and human survival strategies. Journal of Geophysical Research 99, B10: 20063-78.

King, G., D. Sturdy \& G. Bailey. 1997. The tectonic background to the Epirus landscape, in G.N. Bailey (ed.) Klithi: Palaeolithic Settlement and Quaternary Landscapes in Northwest Greece: Volume 2: Klithi in its Local and Regional Setting: 541-59. Cambridge: McDonald Institute for Archaeological Research.

King, G., D. Sturdy \& J. Whitney. 1993. The landscape geometry and active tectonics of Northwest Greece. Geological Society of America Bulletin 105: 37-161.

KLeIN, R.G. 1999. 2nd Edition. The Human Career. Chicago: University of Chicago Press.

Kuman, K. 1998. The earliest South African industries, in M.D. Petraglia \& R. Korisettar (ed.) Early Human Behaviour in Global Context: 451-68. London: Routledge.

Lordkipanidze, D., O. Bar-Yosef \& M. Otte (ed.). 2000. Early Humans at the Gates of Europe: Proceedings of the First International Symposium, Dmanisi, Tbilisi (Georgia) September 1998. Liège: Etudes et Recherches Archéologiques de l'Université de Liège (E.R.A.U.L.) 92.

Macaulay, V., C. Hill, A. Achilli, C. Rengo, D. Clarke, W. Meehan, J. Blackburn, O. Semino, R. Scozzari, F. Cruciani, A. Taha, N. Kassim ShaAri, J. Maripa Raja, P. Ismail, Z. Zainuddin, W. Goodwin, D. Bulbeck, H.-J. Bandelt, S. Oppenheimer, A. Torroni \& M. Richards. 2005. Single, rapid coastal settlement of Asia revealed by analysis of complete mitochondrial genomes. Science 308: 1034-36.

Manighetti I., G. King, Y. Gaudemer, C. Scholz \& C. Doubre. 2001. Slip accumulation and lateral propagation of active normal fault in Afar. Journal of Geophysical Research 106: 13667-96.

Mithen, S.J.M. \& M. Reed. 2002. Stepping out: a computer simulation of hominid dispersal from Africa. Journal of Human Evolution 43: 433-62.

Moctar Doucouré, C. \& J. De Wit Maarten. 2003. Old inherited origin of the present near-bimodal topography of Africa. Journal of African Earth Science 36: 371-88.
Partridge, T.C., G.C. Bond, C.J.H. Hartnady, P.B. deMenocal \& W.F. Ruddiman. 1995a. Climatic effects of late Neogene tectonism and volcanism, in E.S.Vrba, G.H. Denton, T.C. Partridge \& L.H. Burckle (ed.) Paleoclimate and Evolution, with emphasis on Human Origins: 8-23. New Haven (CT) \& London: Yale University Press.

Partridge, T.C., B.A. Wood \& P.B. deMenocal. $1995 \mathrm{~b}$. The influence of global climatic change and regional uplift on large-mammalian evolution in east and southern Africa, in E.S.Vrba, G.H. Denton, T.C. Partridge \& L.H. Burckle (ed.) Paleoclimate and Evolution, with emphasis on Human Origins: 331-55. New Haven (CT) \& London: Yale University Press.

Partridge, T.C. 1997. Late Neogene uplift in eastern and southern Africa and its paleoclimatic implications, in W.F. Ruddyman (ed.) Tectonic Uplift and Climate Change: 63-86. NY \& London: Plenum Press.

Petraglia, M.D. 2003. The Lower Palaeolithic of the Arabian Peninsula: occupations, adaptations, and dispersals. Journal of World Prehistory 17: 141-79.

Pоттs, R. 1988. Early Hominid Activities at Olduvai. New York: Aldine.

-1996. Humanity's Descent: the Consequences of Ecological Instability. New York: William Morrow.

Potts, R., A.K. Behrensmeyer \& P. Ditchfield. 1999. Palaeolandscape variation and Early Pleistocene hominid activities: Members 1 and 7 , Olorgesailie Formation, Kenya. Journal of Human Evolution 37: 747-88.

Raynal, J.P., F.Z. Sbihi Alaoui, D. Gerards, L. Magoga \& A. Mohi. 2001. The earliest occupation of North Africa: the Moroccan perspective, in L.G. Straus \& O. Bar-Yosef (ed.) Out of Africa in the Pleistocene: An Introduction. Quaternary International 75: 65-75.

Redfield, T.F., W.H. Wheeler \& M. Often. 2004. A kinematic model for the development of the Afar depression and its palaeogeographic implications. Earth and Planetary Science Letters 216 (3): 383-98.

ReED, K.E. 1997. Early hominid evolution and ecological change through the African PlioPleistocene. Journal of Human Evolution 32: 289-322.

Rogers, M.J., J.W.K. Harris \& C.S. Feibel. 1994. Changing patterns of land use by Plio-Pleistocene hominids in the Lake Turkana Basin. Journal of Human Evolution 27: 139-58.

Rolland, N. 1998. The Lower Palaeolithic settlement of Eurasia, with special reference to Europe, in M.D. Petraglia \& R. Korisettar (ed.) Early Human Behaviour in Global Context: 187-220. London: Routledge. 


\section{Tectonics and human evolution}

Ron, H. \& S. Levi. 2001. When did hominids first leave Africa? New high-resolution paleomagnetic evidence from the Erk-El-Ahmar formation, Israel. Geology 29: 887-90.

Ruddiman, W.F. \& M.E. Raymo. 1988. Northern Hemisphere climate regimes during the past 3Ma: possible tectonic connections, in N.J. Shackleton, R.W. West \& D.Q. Bowen (ed.) The Past Three Million Years: Evolution of Climatic Variability in the North Atlantic Region: 1-20. London: Royal Society.

SAUER, C.O. 1962. Seashore -primitive home of man? Proceedings of the American Philosophical Society 106: 41-7.

Salabi K.M. 1988. A House of Many Mansions. Berkeley: University of California Press.

Scotese, C.R. \& W.S. McKerrow. 1991. Revised world maps and introduction. Paleozoic Paleogeography and Biogeography: 1-21. Geological Society Memoir 12.

Senut, B., M. Pickford, D. Gommery, P. Mein, C. Cheboi \& Y. Coppens. 2001. First hominid from the Mocene (Lukeino Formation, Kenya). Comptes rendus des sciences d l'academie des sciences 3332: 137-44.

SneH, A., Y. Bartov \& M. Rosensaft. 1998. Geological Map of Israel. Jerusalem: Geological Survey of Israel.

Stern, N. 1993. The structure of the Lower Pleistocene archaeological record: a case study from the Koobi Fora Formation. Current Anthropology 34: 201-25.

-1994. The implications of time-averaging for reconstructing the land-use patterns of early tool-using hominids. Journal of Human Evolution 27: $89-105$.

Straus, L.G. 2001. Africa and Iberia in the Pleistocene, in L.G. Straus \& O. Bar-Yosef (ed.) Out of Africa in the Pleistocene: An Introduction. Quaternary International 75: 91-102.

Stringer, C. 2000. Coasting out of Africa. Nature 405: 53-5.

Sturdy, D., D. Webley \& G. Bailey. 1997. The palaeolithic geography of Epirus, in G. Bailey (ed.) Klithi: Palaeolithic Settlement and Quaternary Landscapes in Northwest Greece: Volume 2: Klithi in its local and regional setting: 587-614. Cambridge: McDonald Institute for Archaeological Research.

Swisher, C.C., G.H. Curtis, T. Jacob, A.G. Getty, A. Suprijo \& Widiasmoro. 1994. Age of earliest known hominids in Java, Indonesia. Science 263: 1118-21.
Tapponnier, P., X. Zhiqin, F. Roger, B. Meyer, N. Arnaud, G. Wittlinger \& Y. Jingsui. 2001. Oblique stepwise rise and growth of the Tibet plateau. Science 294: 1671-77.

Thomas, H. 1985. The Early and Middle Miocene land connection of the Afro-Arabian plate and Asia: a major event for hominoid dispersal?, in E. Delson (ed.) Ancestors: the Hard Evidence: 42-50. New York: Alan Liss.

Turner, A. 1992. Large carnivores and earliest European hominids: changing determinants of resource availability during the Lower and Middle Pleistocene. Journal of Human Evolution 22: 109-26.

-1999. Assessing earliest human settlement of Eurasia: late Pliocene dispersions from Africa. Antiquity 73: 563-70.

Vermeersch, P.M. 2001. 'Out of Africa' from an Egyptian point of view, in L.G. Straus \& O. Bar-Yosef (ed.) Out of Africa in the Pleistocene: an introduction. Quaternary International 75: 103-12.

Walters, R.C., R.T. Buffler, J.J. BruggemanN, M.M.M. Guillaume, S.M. Berhe, B. Negassi, Y. Libsekal, H. Cheng, R.L. Edwards, R. von Gosel, D. Neraudeau \& M. Gagnon. 2000. Early human occupation of the Red Sea coast of Eritrea during the Last Interglacial. Nature 405: 65-9.

Whalen, N.M. \& G.A. Fritz. 2004. The Oldowan in Arabia. Adumatu 9: 7-18.

WheELER, P.E. 1991. The thermoregulatory advantages of hominid bipedalism in open equatorial environments: the contribution of increased convective heat loss and cutaneous evaporative cooling. Journal of Human Evolution 21: 107-15.

WoldeGabriel, G., P.R. Renne, W.K. Hart, S. Ambrose, B. Asfaw \& T.D. White. 2004. Geoscience methods lead to paleo-anthropological discoveries in Afar Rift, Ethiopia. EOS, Transactions, American Geophysical Union 85 (29): 273-7.

Zhu, R.X., R. Ротts, F. Xie, K.A. Hoffman, C.L. Deng, C.D. ShI, Y.X. Pan, H.Q. Wang, R.P. ShI, Y.C. WANG, G.H. SHI \& N.Q. Wu. 2004. New evidence on the earliest human presence at high northern latitudes in northeast Asia. Nature 431: 559-62. 